\title{
CURRENT TRENDS IN THE SLOVAK LEGAL SYSTEM IN THE AREA OF WASTE MANAGEMENT*
}

\author{
LUCIA ČERŇANOVÁ, MARTIN DUFALA, MATÚŠ \\ MICHALOVIČ**
}

\begin{abstract}
Current Trends in the Slovak Legal System in the Area of Waste Management
Authors discuss actual state in the area of waste management in the Slovak Republic in the light of achieving recycling targets and obligations arising from the legislation of the European Union. The article presents and explains current trends, policies and legislation in this area in the Slovak Republic with emphasis on introducing the new piece of legislation Act No. 329/2018 Coll. on fees for the waste landfilling.
\end{abstract}

Keywords: waste management; recycling; fees for waste landfilling; municipal waste

Klíčová slova: odpadové hospodářství; recyklace; poplatky za ukládání odpadů; komunální odpad

DOI: $10.14712 / 23366478.2019 .31$

The European Union (hereinafter referred to as "EU") started to switch from linear to a circular economy, which is seen as an opportunity to transform European economy in order to make it more sustainable. The idea is to switch to a model where products, materials, and resources are maintained and used for as long as possible. Efficient waste prevention and management is an essential building block of the circular economy as it both helps prevent waste from having a negative impact on the environment and health, and directs it to efficient use. In order to achieve this transformation, the EU sets ambitious targets in waste management in the Waste Framework Directive. ${ }^{1}$ There are two main targets that should be achieved by the year $2020 .^{2}$

* The article was elaborated within the VEGA grant No. 1/0557/17 "Legal Aspects of Optimalization of Exercising Public Administration Competences by Local Self-Government Authorities as Public Administration entities" awarded by the Scientific Grant Agency of the Ministry of Education, Science, Research and Sport of the Slovak Republic and the Slovak Academy of Sciences.

** Authors operates at the Department of Administrative Law and Environmental Law at the Faculty of Law at the Comenius University in Bratislava. Michalovič and Dufala works as assistant professors and Čerňanová is $\mathrm{PhD}$. student at this department.

1 Directive 2008/98/EC of the European Parliament and of the Council of 19 November 2008 on waste and repealing certain Directives.

2 Provision of point (a) of paragraph 2 of Article 11 of the Directive 2008/98/EC of the European Parliament and of the Council of 19 November 2008 on waste and repealing certain Directives: "the preparing for re-use and the recycling of waste materials such as at least paper, metal, plastic and glass from households 
Paragraph 2 of article 11 was amended in $2018^{3}$ and by this amendment, these two targets were extended by three additional targets for additional time periods. ${ }^{4}$

In order to achieve these targets, those member states shall take all the necessary measures. However, the report on the implementation of EU waste legislation from 2018 concludes that 14 Member States have been identified as at risk of missing the 2020 target of $50 \%$ recycling of the municipal waste. ${ }^{5}$ To the same conclusion came the Environmental Implementation Review 2019 published in April of this year. ${ }^{6}$ The report from 2018 provides an overview of progress and implementation challenges for several waste streams, including municipal waste, construction and demolition waste, hazardous waste, waste electrical and electronic equipment, packaging waste, and suggests areas for improvement for each of the country. Positively could be seen that the EU does not limit themselves to only stating that some of the countries are not on the track to meet their targets, but also elaborated warning reports to those states, where are listed possible actions to support their efforts to improve their performance in the area of waste management. ${ }^{7}$ In the following text, we would like to focus on the current state of the waste management in the Slovak Republic and policies and legislation adopted in order to improve it.

\section{CURRENT STATE OF WASTE MANAGEMENT IN THE SLOVAK REPUBLIC AND FRAMEWORK POLICIES}

The Slovak Republic belongs to countries where the landfilling represents the most widely used method of waste disposal. According to the Slovak legislation,

and possibly from other origins as far as these waste streams are similar to waste from households, shall be increased to a minimum of overall 50\% by weight" and Provision of point (b) of paragraph 2 of Article 11 of the Directive 2008/98/EC of the European Parliament and of the Council of 19 November 2008 on waste and repealing certain Directives: "the preparing for re-use, recycling and other material recovery, including backfilling operations using waste to substitute other materials, of non-hazardous construction and demolition waste excluding naturally occurring material defined in category 170504 in the list of waste shall be increased to a minimum of $70 \%$ by weight".

3 Directive (EU) 2018/851 of the European Parliament and of the Council of 30 May 2018 amending Directive 2008/98/EC on waste.

4 Provision of point (c) of paragraph 2 of Article 11 of the Directive 2008/98/EC of the European Parliament and of the Council of 19 November 2008 on waste and repealing certain Directives: "the preparing for re-use and the recycling of municipal waste shall be increased to a minimum of $55 \%$ by weight by 2025 "; Provision of point (d) of paragraph 2 of Article 11 of the Directive 2008/98/EC of the European Parliament and of the Council of 19 November 2008 on waste and repealing certain Directives: "the preparing for reuse and the recycling of municipal waste shall be increased to a minimum of $60 \%$ by weight by 2030 " and Provision of point (e) of paragraph 2 of Article 11 of the Directive 2008/98/EC of the European Parliament and of the Council of 19 November 2008 on waste and repealing certain Directives: "the preparing for re-use and the recycling of municipal waste shall be increased to a minimum of $65 \%$ by weight".

5 Bulgaria, Croatia, Cyprus, Estonia, Finland, Greece, Hungary, Latvia, Malta, Poland, Portugal, Romania, Slovakia and Spain

6 Communication from the Commission to the European Parliament, the Council, the European and Social Committee and the Committee of the Regions: Environmental Implementation Review 2019: "A Europe that protects its citizens and enhances their quality of life." COM (2019) 149.

7 Commission staff working document: The early warning report for Slovakia, SWD (2018). This report recommended totally 19 possible action divided into these areas: Economic incentives for municipalities, Extended producer responsibility schemes, Engagement from municipalities, Spending of EU funds, Incentives for households, Management of bio-waste, Technical support to municipalities, Improving data quality. 
the term landfilling means "the deposition of waste at a landfill" 8 and "landfill means a site with a waste disposal installation where waste is permanently deposited onto or into the land. An internal landfill where waste is disposed of by a waste producer at the site of production or a site permanently, i.e. for a period longer than one year, used for the preliminary storage of waste, shall also be considered a landfill. An installation or a site with an installation where waste is stored for the purpose of preparing it before any further transfer to another location where it will be processed, recovered or disposed of shall not be considered a landfill if the period preceding the recovery or processing thereof does not, as a rule, exceed three years or the period preceding the disposal thereof does not exceed one year."

The Ministry of Environment of the Slovak Republic annually publishes reports on the state of the environment, summarizes the causes and consequences of this state, describes the measures to protect and improve the environment and discloses new trends and international cooperation. According to these reports in the year 2015 the Slovak Republic produced around 10,563,398.07 tons of waste, of which 1,888,455.62 tons was a municipal waste. These facts confirmed that $348 \mathrm{~kg}$ of municipal waste per capita was generated in 2015. The landfilling in this year accounted for $37 \%$ of total waste disposal and landfilling of municipal waste accounted for $69 \%$. According to the Commission Decision 2011/753/EU, the recycling rate of municipal waste in 2015 reached only $20.11 \%$ in the Slovak Republic.

In the year 2016, the unfavorable disposal of municipal waste persisted. The production of municipal wasted in 2016 increased compared to the year 2015. The amount of municipal waste produced in 2016 was around 1,953,478.2 tons which means $359 \mathrm{~kg}$ of municipal waste per capita. The recycling rate increased from $20.11 \%$ to $23 \%$. The landfilling rate was at the level of $66 \%$.

A total of 14,269,664.35 tons of waste was generated in 2017 in the Slovak Republic. Compared to 2016, the year-on-year increase in total waste generation in 2017 is almost $34 \%$. This increase was mainly due to increased activity in the construction and modification of road and rail networks. The amount of produced municipal waste in 2017 was $2,136,787$ tons and it caused an increase in the amount of municipal waste per capita that accounted for $33 \mathrm{~kg}$. Landfilling rate of municipal waste was $61 \%$.

The reports reflecting the state from the years 2018 and 2019 have not published yet but the situation is very similar to previous years. In Europe-wide comparison, the Slovak Republic is among the countries with the lowest municipal waste production but at the same time among the countries with the lowest recycling rate. Based on these facts, increasing recycling, rolling-out separate collection and reducing landfilling are the most important targets in the area of waste management.

Several strategic documents adopted in the area of environment highlight the problem of our waste management and set out the most important goals and measures aiming to secure better conditions on how to improve the current situation. For instance, the Strategy of the Environmental Policy of the Slovak Republic until 2030

8 Provision of paragraph 16 of te Article 3 of the Act No. 79/2015 Coll. on waste and on amendments to certain acts as amended (hereinafter referred to as "Waste Act").

9 Provision of paragraph 5 of the Article 5 of the Waste Act. 
called Greener Slovakia adopted in February 2019 sets out that recycling rate of municipal waste should increase to $60 \%$ till 2030 and the landfilling should reduce to less than $25 \%$ till 2035 . This Strategy includes very ambitious goals considering the actual situation of waste management in the Slovak Republic. A gradual increase in recycling and decrease of landfilling have to be supported by other measures, too. According to this Strategy, the Slovak Republic will try to ensure better monitoring aim to improve the quality of collected information and subsequently to provide them into the public sector and to use them for creation of other different plans and policies. Consideration will be given to the deposit system expansion of single-use drinks containers and the limitation of the use of disposable plates and other containers. The creation of re-use centers will be considered as well mainly for the opportunity for citizens to hand over the items which could be used again or repaired and re-used. ${ }^{10}$ The changes will affect the area of waste charges because the gradual increasing of waste charges could help to the prevention of landfilling, waste generation and lead to an increase in the recycling rate.

Waste management legislation includes the obligation to prepare waste prevention programs for the Slovak Republic in compliance with the EU waste management targets. The first program was elaborated for years 2014-2018 and the next one for the period of years 2019-2025. The main aim of the document adopted for years 2019-2025 is the prevention of waste generation in compliance with the EU Action Plan for Circular Economy. Several measures in the area of waste management are expected such as: - coordination of waste management activities with the activities in the area of producers and consumers policy,

- increasing the fees for landfilling,

- promoting waste prevention in the policy documents of other sectors concerned,

- improving public awareness of waste prevention,

- consistent application of the principles of green public procurement by the competent authorities,

- implementation of voluntary environmental policy instruments. ${ }^{11}$

The most important strategic document in the area of waste management is The Program of Waste Management of the Slovak Republic for years 2016-2020 corresponding to the Slovak and EU legislative requirements. According to this Program, the reduction of landfilling is not satisfactory and this state is not acceptable for the future mainly because of the trends leading to sustainable development and transformation to the recycling society.

One of the main aims is to intensify the separate collection of biodegradable waste to fulfill the EU targets for 2020. It is more than likely that the Slovak Republic will not fulfill the targets set by the Program of Waste Management and the EU targets set by waste directives. In the next period, it will be necessary to follow the previous strategic documents and take appropriate measures also in the legislative area.

10 Strategy of the Environmental Policy of the Slovak Republic until 2030 - Greener Slovakia.

11 The waste prevention program of Slovak Republic for years 2019-2025. 


\section{NEW ACT ON FEES FOR THE WASTE LANDFILLING}

The new act No. 329/2018 Coll. on fees for the waste landfilling and on amending and supplementing to Act No. 587/2004 Coll. on the Environmental Fund and on amending and supplementing certain acts as amended (hereinafter referred to as "Act on fees"), replacing Act No. 17/2004 Coll. on fees for the waste landfilling, was adopted in 2018 and came into force on the 1st of the January 2019. This new act was adopted for several reasons: the Slovak Republic has one of the highest percentage of landfilled waste among EU member states and at the same time one of the lowest fee for landfilling. The Act on fees aiming to put landfilling of the waste at disadvantage and create incentive factors for separate collection of municipal waste and increase the recycling of municipal waste. ${ }^{12}$ We recognize both positive and negative incentive factors incorporated in this act. This part of the article aimed to explain provisions dealing with municipal waste only and therefore optimization of the municipal waste management. The Act on fees regulates the process of determining the specific fee amount as follows. All municipalities are obliged to pay a fee for landfilling mixed municipal waste and bulky waste. The amount of waste to be charged for depositing at a landfill is determined by the landfill operator by weighing it at the landfill. Then the fee for landfilling municipal waste is calculated by the landfill operator by multiplying the amount of waste and the rate for the waste, stipulated in the Annex No. 1 to the Regulation of the Government of the Slovak Republic No. 330/2018 Coll. laying down the rates of fees for waste disposal and details related to the redistribution of revenues from waste disposal fees (hereinafter referred to as "Regulation"). ${ }^{13}$ When storing mixed municipal waste and bulky waste at a landfill, the applicable rate is determined based on the municipal waste sorting level. The level of municipal waste sorting is calculated according to the formula given in Annex No. 2. ${ }^{14}$ The specific fee varies by this sorting level and as shown in the table No. 1 , the range is very wide (from $7 €$ to $17 €$ in the year 2019 and from $11 €$ to $33 €$ in the year 2021 and following years). This should pressure on the municipalities to improve their separate municipal waste collection systems and we believe that it will indirectly put pressure on the citizens to recycle more. ${ }^{15}$

12 The general part of the explanatory memorandum to the Act on fees.

${ }_{13}$ Provision of paragraph 3 of Article 4 of the Act on fees.

14 Municipal waste sorting level is calculating by summing all the weights of the sorted municipal waste components collected in the municipality in the previous calendar year as part of a separate municipal waste collection system divided by the weight of municipal waste generated in the municipality for the previous calendar year and multiplied this number by 100 (in order to get percentage).

15 If the municipality pays more for landfilling, it is most likely to pass on these additional financial costs to taxpayers, for example by increasing the fees for municipal waste. 


\begin{tabular}{|c|c|c|c|c|}
\hline \multirow{2}{*}{ Entry } & \multirow{2}{*}{$\begin{array}{c}\text { Municipal waste sorting } \\
\text { level x [\%] }\end{array}$} & \multicolumn{3}{|c|}{ The rate for the year $\mathrm{t}^{-1}$} \\
\hline & & 2019 & 2020 & 2021 and following years \\
\hline 1 & $x \leq 10$ & 17 & 26 & 33 \\
\hline 2 & $10<x \leq 20$ & 12 & 24 & 30 \\
\hline 3 & $20<x \leq 30$ & 10 & 22 & 27 \\
\hline 4 & $30<x \leq 40$ & 8 & 13 & 22 \\
\hline 5 & $40<x \leq 50$ & 7 & 12 & 18 \\
\hline 6 & $50<x \leq 60$ & 7 & 11 & 15 \\
\hline 7 & $x>60$ & 7 & 8 & 11 \\
\hline
\end{tabular}

Tab. 1. Items and rates for the storage of mixed municipal waste and bulky waste at the landfills. Source: Annex No. 1 to the Regulation.

As we already mentioned we recognize also positive incentive factors in this Act represented by the system and the way in which revenue from fees for waste landfilling is distributed. The recipient of the revenue is Environmental Fund and the Act on fees established system how the Environmental Fund will use this revenue. There are four main ways and we will elucidate two most important of them from the point of view of the municipalities as local self-government authorities responsible for municipal waste management at their territories. The other two ways of usage of the revenue are: for natural persons - entrepreneurs or legal entities conducting business in waste management; for natural persons - entrepreneurs and legal entities who can demonstrate that they will reduce waste production as part of their production process.

First way how the Environment Fund will use revenue is for the municipalities in which territories the waste landfills or waste ponds are located, and municipalities through which the special purpose roads ${ }^{16}$ are going. Each municipality will use this income for waste management purposes of the municipality in accordance with the hierarchy and objectives of waste management. ${ }^{17}$ However, the Act on fees limited this use by laying down one restriction: a reduction in the fee for municipal waste and small construction waste ${ }^{18}$ is not considered to be the purpose of being used for waste management. There is also a second option as such municipality can use this income to improve the environment in the village/city. ${ }^{19}$ This wording is very vague and by the "improving of the environment" we can understand for example: adjustment of the public area of the village (construction and repair of general shelters, playground),

16 Provision of point (e) of Article 2 of the Act on fees: "access roads - purpose-built communication, which is specified in the occupancy permit and leads to a waste landfill and starts with connection from the relevant class road or local road and ends at the lockable gate of the waste landfill; reinforced communication in the area of the landfill site is not considered as the special purpose road".

17 Provision of paragraph 5 of Article 7 of the Act on fees.

18 This fee is levied in accordance with Act No. 582/2004 Coll. on Local Taxes and Local Fee for Municipal Waste and Small Construction Waste as amended.

19 Provision of paragraph 7 of Article 7 of the Act on fees. 
construction of sewerage and wastewater treatment, maintenance of local roads and pavements and their cleaning, management and maintenance of public greenery etc. In order to be legally authorized to use income in these ways, the municipality must fulfill two legal conditions: the municipality has not been sanctioned for a breach of violating the Waste Act in the past 3 years ${ }^{20}$ and in the calendar year preceding the calendar year in which the municipality intends to use this income for a purpose other than waste management the municipality reached municipal waste sorting level at least 60 percent. $^{21}$

The second way how the Environment Fund will use revenue is for the municipalities in which are not any waste landfills or waste ponds located, and without purpose roads $^{22}$ in their territories. Municipality wishing to obtain such income has to fulfill two conditions in order to get it and submit an application for it by 31 st March of the relevant year. ${ }^{23}$ The first condition is the same as in a previous way - the municipality has not been sanctioned for a breach of violating the Waste Act in the past 3 years. ${ }^{24}$ The second one relates to the municipal waste sorting level that needs to be achieved in order to be entitled to receive such income from the Environmental Fund. In the year 2019 municipality need to achieve municipal waste sorting level at least $30 \%$, in the year 2020 at least $33 \%$ and in the year 2021 and following years at least $35 \% .25$ The ways how municipalities can use this revenue are the same as in the previous paragraph.

\section{CONCLUSIONS}

As mentioned above, the Slovak Republic probably will not achieve the required waste management targets by 2020 . However, it is necessary for the Slovak Republic to adopt measures and instruments to achieve the set waste management targets for the next periods. The recommendations of the European Commission in Environmental Implementation Review 2019 (Country Report - Slovakia) should serve as an inspiration.

A key step will be the adoption of measures that put the deposition of waste at a landfill at a disadvantage and encourage higher waste separation and subsequent waste recovery in accordance with the waste management hierarchy.

In addition to the measures supporting the separation and recovery of waste, another option is to apply the "polluter pays" principle more widely. One of the possibilities of its application, which is already effective, is the new legislation - Act on fees. The law applies to municipalities, but a similar philosophy could also apply to waste producers,

20 Provision of point (a) of paragraph 7 of Article 7 of the Act on fees.

21 Provision of point (b) of paragraph 7 of Article 7 of the Act on fees.

22 Provision of point (e) of Article 2 of the Act on fees: "access roads - purpose-built communication, which is specified in the occupancy permit and leads to a waste landfill and starts with connection from the relevant class road or local road and ends at the lockable gate of the waste landfill; reinforced communication in the area of the landfill site is not considered as the special purpose road".

23 Provision of point (d) of paragraph 9 of Article 7 of the Act on fees.

24 Provision of point (b) of paragraph 9 of Article 7 of the Act on fees.

25 Annex No. 5 to the Regulation. 
whether they are households or entrepreneurs in order to achieve a higher recycling rate across the whole spectrum.

We believe that improving waste management outcomes and achieving the targets set out in the Waste Framework Directive will be possible by combining both types of instruments and measures - motivation to increase separation and for higher levels of recovery, as well as a gradual increase fees for landfilling.

\author{
Mgr. Lucia Čerňanová \\ Faculty of Law, Comenius University in Bratislava \\ lucia.cernanova@flaw.uniba.sk \\ Mgr. Martin Dufala, Ph.D. \\ Faculty of Law, Comenius University in Bratislava \\ martin.dufala@flaw.uniba.sk \\ JUDr. Matúš Michalovič, Ph.D. \\ Faculty of Law, Comenius University in Bratislava \\ matus.michalovic@flaw.uniba.sk
}

